\title{
Statyba
}

\section{ANALYSIS OF CYCLIC FRACTURE OF THE THREADED JOINTS}

\section{Leonavičius \& S. Stupak}

To cite this article: M. Leonavičius \& S. Stupak (2000) ANALYSIS OF CYCLIC FRACTURE OF THE THREADED JOINTS, Statyba, 6:2, 97-103, DOI: 10.1080/13921525.2000.10531572

To link to this article: https://doi.org/10.1080/13921525.2000.10531572

曲 Published online: 26 Jul 2012.

Submit your article to this journal

山 Article views: 57 


\section{SRIEGINIŲ JUNGČIŲ CIKLINIO IRIMO SĄLYGŲ ANALIZE்}

\author{
M. Leonavičius, S. Stupak \\ Vilniaus Gedimino technikos universitetas
}

\section{Ivadas}

Energetiniu, cheminiu̧, transporto, kalnakasybos irenginių ir mašinu, statybinių konstrukcijų ilgaamžiškumo ir patikimumo didinimas susijęs su daugeliu veiksnių, kurie daro itaką ribiniams būviams ir lemia atskirų elementų ir visos konstrukcijos stiprumą. Jeigu konstrukcijos nuo pat pagaminimo turi pradiniu defekty arba jeigu jie atsirado eksploatacijos metu, tai saugiam darbui būtina, kad tie defektai nepasiektu kritinių dydžių. Visu pirma reikia išmatuoti defektus, o po to apskaičiuoti ju plitimą lemiančius parametrus. Turi būti numatyta pažeidimų kontrolè gamybos proceso ir eksploatacijos metu. Konstrukcijos elemento stiprumo įvertinimas, aptikus defektą arba plyši, yra gana sudètingas procesas, kuriam kartais reikia papildomų teorinių sprendinių arba eksperimentinių tyrimų.

Praktikai yra svarbios įvairios ribinio būvio sąlygos, kurioms susidarius plyšys neplinta. Jeigu šios sąlygos išlaikomos, manoma, kad konstrukcijos elementas su neplintančiu plyšiu visiškai tinkamas naudoti eksploatuojamame objekte.

Konstrukciniai ir technologiniai privalumai lemia srieginiu jungčiu naudojimą ivairiems mazgams ir atskiriems elementams sujungti. Suirimy analizè rodo, kad i srieginę jungtị reikia žiūrèti kaip ị sistemą, sudarytą iš atskiru elementu (varžtas-veržlès, varžtas-korpusas), kurie veikia vienas kitą ir kartu su kitais veiksniais lemia varžto (silpniausios grandies) ciklini ilgaamžiškumą. Eksperimentiniai ir teoriniai šio reiškinio tyrimai, naudojant plokščius, tūrinius ir skaičiuojamuosius modelius, neduoda pakankamai tikslaus rezultato, nes neatkuria sriegio sukabinimo darbo sąlygu.

Tinkamai sukonstruota srieginė jungtis (be technologinių ir surinkimo defektu) suirs taip: statinio apkrovimo metu tik lygioje dalyje, o ciklinio apkrovimo metu varžto-veržlès sukabinimo sriegineje dalyje. Visi kiti galimi literatūroje aprašyti suirimo atvejai gali būti pašalinti parenkant sistemos varžtas-veržlès geometrinius parametrus, medžiagą ir gamybos technologiją. Reglamentuojamas ilgaamžiškumas labai priklauso nuo srieginių jungčių medžiagos, jos terminio apdorojimo, sriegio profilio formavimo, surinkimo technologijos, ivairiapusès paruošos ir po to atliekamu technologinių operacijų kontrolès [1-7].

Straipsnyje apžvelgiami tyrimai [8-12] ir pateikiami nauji rezultatai apie trumpu plyšiu plitimą srieginèse jungtyse. Plyšio susidarymo sąlygoms nagrineti imta lygaus bandinio patvarumo riba ir ittempimu būvis sriegio ¿duboje. Palyginami duomenys apie plyšio plitimą srieginèse jungtyse ir bandiniuose su žiedine išpjova nuo plyšio atsiradimo iki visiško suirimo.

Atsparumo cikliniam irimui, plyšio atsiradimo ir plitimo désningumų ìvertinimo metodų tobulinimas yra aktualus: leidžia patobulinti skaičiavimo metodikas, atsižvelgiant $\mathfrak{i}$ gautus teorinius ir eksperimentinius tyrimo rezultatus, būdingus tik srieginèms jungtims.

\section{Atsparumas cikliniam irimui}

Plyšio atsiradimas ir jo plitimas yra du atskiri ciklinio irimo etapai. Tačiau ciklinèms apkrovoms veikiant tam tikrame medžiagos tūryje šie du etapai yra panašūs, todèl nagrinèjamu požiūriu jie gali būti atskirti arba sujungti. Plyšio plitimo greitis yra vienas iš pagrindinių medžiagos ir konstrukcijos elemento atsparumo cikliniam irimui rodikliu. Pagal bandymo duomenis šis dydis yra nesunkiai apskaičiuojamas. Kebliau būna, kai reikia nustatyti analitini jo ryši su kitais rodikliais, lemiančiais plyšio plitimą, t. y. su parametrais, apibūdinančiais medžiagos savybes, apkrovos lygi ciklo asimetriją ir kt. Š neapibrežtumą rodo daugelis empirinių formulių $[6,7]$, apytiksliai aprašančiu plyšio plitimo greiti. Šiose priklausomybèse galima išskirti parametrus, apibūdinančius apkrovimo sąlygas ir medžiagos savybes. Tačiau kiekvienu konkrečiu atveju, ypač nagrinejjant ciklini irimą konstrukcijos elementu, kurie veikia vienas kitą (sistemoje varž- 
tas-veržlè), reikia nuspręsti, kurie parametrai j̇skaitytini ir kurie iš ju yra vyraujantys irimo procese.

Itempimų būvis, konstrukciniai ir technologiniai ypatumai, apkrovimo lygis, ciklo asimetrija ir kiti veiksniai, kurie lemia plyšio susidarymą ir plitimą srieginèse jungtyse, taikant irimo mechanikos kriterijus, nagrinèjami darbuose [8-12]. Irimo proceso dèsningumai, atsižvelgiant $\mathfrak{i}$ konstrukcinius ypatumus, gamybos technologija ir apkrovimo sąlygas, buvo tiriami srieginèse jungtyse nuo M8 iki M48. Išbandytos srieginès jungtys pagal sistema veržlè-smeigè-veržlè ir veržlè-smeigè-korpusas, pagamintos iš plieno 25XIM $\Phi$ ir 20XIMIФITP, kurie plačiai naudojami gaminti energetiniu irenginių tvirtinimo elementams. Po skirtingo terminio apdorojimo (grūdinimo, normalizacijos, atkaitinimo) mechaniniu savybiu rodikliai: $\quad \sigma_{0,2}=780 \div 1020 \mathrm{MPa} ; \quad \sigma_{u}=830 \div 1120 \quad \mathrm{MPa}$; $\Psi=58 \div 62 \%$. Veržlès pagamintos iš to paties plieno kaip ir smeigè arba iš kito plieno, turinčio skirtingus mechaninių savybiu rodiklius.

Plyšio plitimo dèsningumai srieginèse jungtyse M20 parodyti 1 paveiksle. Kinetiniu nuovargio kreivių tiesiaja dalį, t. y. antraji etapa (pagal iprastinę irimo mechanikoje metodika) galima aprašyti P. Pariso lygtimi:

$$
\frac{d h}{d N}=C(\Delta K)^{n}
$$

čia $d h / d N$ - plyšio greitis; $\Delta K=K_{\max }-K_{\min }$ - ittempimy intensyvumo koeficiento kitimo intervalas, kuris apskaičiuojamas pagal S. Jariomos [8] formulę; $C, n-$ parametrai, apskaičiuojami pagal eksperimentinius duomenis (pateikti 1 lentelèje).

Kinetinèse nuovargio diagramose išryškèja ciklo asimetrijos itaka, kuriai ivertinti pritaikyta R. Formano lygtis:

$$
\frac{d h}{d N}=\frac{C(\Delta K)^{n}}{(1-r) K_{c}-\Delta K},
$$

cia $r$ - ciklo asimetrijos koeficientas; $K_{c}$ - itempimy intensyvumo koeficientas trapaus irimo stadijoje; $C$ ir $n$ parametrai, nustatomi pagal kinetines nuovargio diagramas. Darbe [9] pateiktos (2) lygties rodikliu reikšmès išbandytoms jungtims.

Cilindrinių bandinių Ø20 su žiedine išpjova, imituojančia sriegio M20 idubą, kinetinès nuovargio diagramos taip pat aprašomos $P$. Pariso lygtimi (1). Parametry $C$ ir $n$ reikšmès priklausomai nuo bandiniu medžiagos pateiktos 2 lentelèje.

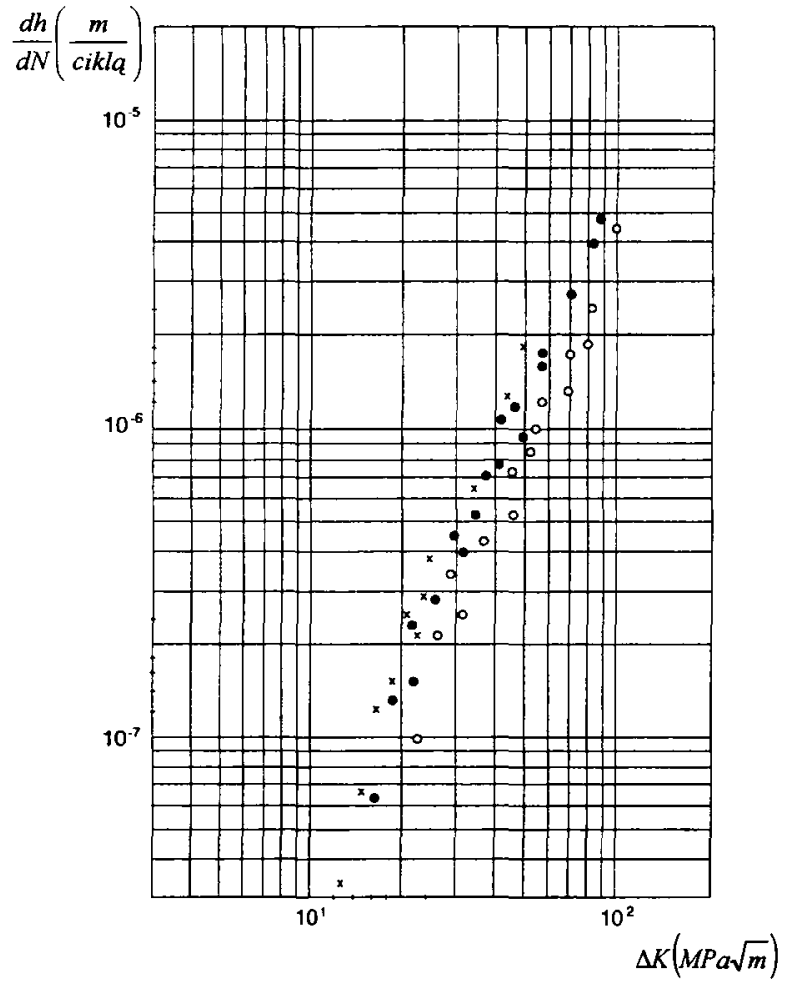

1 pav. Plyšio plitimo greičio priklausomybè nuo $\Delta K$ srieginèse jungtyse iš plieno 25XIMФ (normalizacija)

Fig 1. Dependence of the crack propagation rate on threaded joint steel 25XIM $\Phi$ (normalising)

1 lentelè. Plyšio plitimo lygties parametrai

\begin{tabular}{|c|c|c|c|c|}
\hline Bandiniai & $n$ & $C(r=0)$ & $C(r=0,3)$ & $C(r=0,6)$ \\
\hline $\begin{array}{l}\text { M20; 25XIMФ } \\
\text { (grūdinimas) }\end{array}$ & 2,6 & $0,289710^{.10}$ & $0,4762 \cdot 10^{-10}$ & $0,7243 \cdot 10^{-10}$ \\
\hline $\begin{array}{l}\text { M20; 25XIM } \Phi \\
\text { (normalizavimas) }\end{array}$ & 2,7 & $0,1884 \cdot 10^{-10}$ & $0,3297 \cdot 10^{-10}$ & $0,6123 \cdot 10^{-10}$ \\
\hline $\begin{array}{l}\text { M20; 25XIM } \Phi \\
\text { (atkaitinimas) }\end{array}$ & 2,82 & $0,1821 \cdot 10^{-10}$ & $0,2428 \cdot 10^{-10}$ & $0,425 \cdot 10^{-10}$ \\
\hline $\begin{array}{l}\text { M20; 25XIMФITP } \\
\text { (grūdinimas) }\end{array}$ & 2,74 & $0,2038 \cdot 10^{-10}$ & $0,3669 \cdot 10^{-10}$ & $0,6931 \cdot 10^{-10}$ \\
\hline
\end{tabular}

Table 1. Parameters of the equation of crack propagation

2 lentelè. Plyšio plitimo lygties parametrai

\begin{tabular}{|c|c|c|}
\hline Bandiniai & $n$ & $C$ \\
\hline $\begin{array}{l}\text { Cilindrinis bandinys; } 25 \mathrm{XIM} \Phi \\
\text { (grūdinimas) }\end{array}$ & 3,52 & $0,0995 \cdot 10^{11}$ \\
\hline $\begin{array}{l}\text { Cilindrinis bandinys; } 25 \mathrm{XIM} \Phi \\
\text { (normalizavimas) }\end{array}$ & 3,4 & $0,1434 \cdot 10^{-11}$ \\
\hline $\begin{array}{l}\text { Cilindrinis bandinys; } \\
\text { 25XIM } \Phi \text { (atkaitinimas) }\end{array}$ & 3,9 & $0,0362 \cdot 10^{-11}$ \\
\hline $\begin{array}{l}\text { Cilindrinis bandinys; } \\
\text { 20XIMIФITP (grūdinimas) }\end{array}$ & 3,6 & $0,1034 \cdot 10^{-11}$ \\
\hline
\end{tabular}

Table 2. Parameters of the equation of crack propagation 
Specifiniams ypatumams, kurie būdingi tik srieginems jungtims, nustatyti buvo atlikti papildomi tyrimai. Žinoma, kad tinkamai sukonstruota srieginè jungtis veržlè-smeigè-veržlè statinio apkrovimo metu suyra smeigès stiebo dalyje (analogiškai kaip ir tempimo atveju). Jeigu smeigeje yra gana didelis plyšys, tai statinio apkrovimo metu suirimas gali ivykti plyšio plokštumoje. Taip tirti buvo trijų tipu bandiniai: cilindriniai bandiniai su plyšiu; smeigès su plyšiu ir srieginès jungtys smeigè-veržlè, kurių smeigèse yra plyšys. Bandymo rezultatai pagal plyšio gyli pateikti 2 paveiksle. Šie duomenys rodo skirtinga visu trijų tipų bandinių pasipriešinimą plyšio plitimui, kuri galima paaiškinti taip:

- skirtingas itempimy būvis smeigès sriegio jduboje (bendras smeigès tempimo ir vijos lenkimo rezultatas) ir cilindrinio bandinio žiedinèje išpjovoje;

- skirtingas plyšio plitimo frontas;

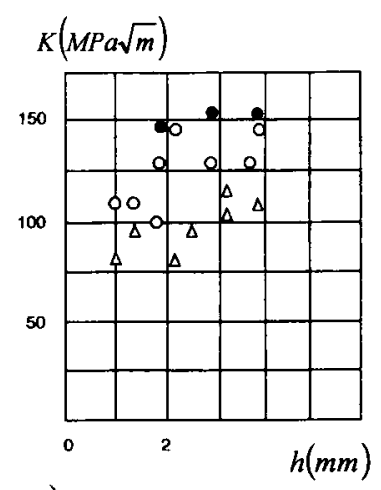

a)

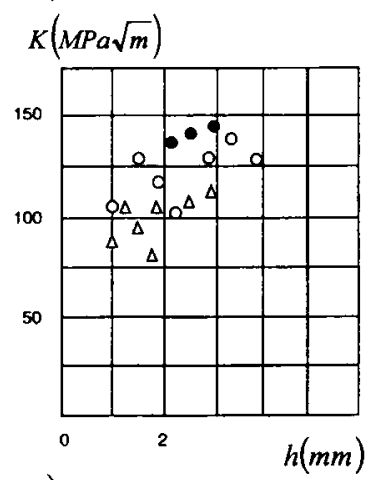

c)

2 pav. Itempimų intensyvumo koeficiento priklausomybe nuo plyšio gylio: $\mathrm{O}$ - smeigèje; - - sistemoje smeigè-veržle; $\Delta$ - cilindriniame bandinyje su žiedine išpjova; $a$ - plienas 25XIM $\Phi$ (grüdinimas); $b$ - plienas 25XIMФ (normalizacija); $c$ - plienas 20XIMIФITP (grūdinimas); $d$-plienas 25XIM $\Phi$ (atkaitinimas)

Fig 2. Dependence of stress intensity ratio on the crack depth: $O$ - in the stud; - in the system 'stud-nut'; $\Delta$ in the cylindrical specimen with a ring notch; $a$ - steel 25XIMФ (hardening); $b$ - steel 25XIM $\Phi$ (normalising); $c$ - steel 20XIMITITP (hardening); $d$ - steel 25XIMT (annealing)
- skirtingas plyšio plitimo kampas (statmenai apkrovai cilindriniame bandinyje ir pagal vijos kilimo kampa smeigeje);

- smeigès ir veržlès sukibusių pirmujjų vijų poveikis, kuris riboja plyšio atsiverimą ir turi itakos procesams, vykstantiems plyšio viršūneje.

Visi šie veiksniai lemia tam tikrą skirtumą tarp kritinių itempimų intensyvumo koeficientų: medžiagos $K_{c}$; smeigès $K_{c b}$ ir smeigès, sukibusios su veržle $K_{c t}$. Jeigu plyšio gylis mažesnis už $0,5 \mathrm{~mm}$, tai statinio apkrovimo metu smeigès suyra kaip cilindrinis bandinys, t. y. smeigès stiebo dalyje susidaro kakliukas.

\section{Plyšio atsiradimo sąlygos}

Pagal [1, 2, 3, 4] ribiniu būviu leistinosios amplitudès skaičiavimui yra laikomas plyšio atsiradimas. Ši sq̨voka yra nepakankamai apibrèžta (turimas omenyje makroplyšys, kurio dydis apie $1 \mathrm{~mm}$ ). Eksploatacijos sąlygomis minimalus imanomas išmatuoti plyšio dydis (paprastai didesnis už $1 \mathrm{~mm}$ ) ir jo tikslumas priklauso nuo turimu matavimo priemonių. Gaminant svarbias sriegines jungtis, taip pat eksploatacijos metu turi būti neardančios kontrolès metodais nustatyta techninè ju būklè. Tai padeda numatyti galimas pasekmes. Konstrukcijos arba mazgo ilgaamžiškumas bus pakankamas ir eksploatacija saugi, jeigu kontrolès metu i plyši panašaus defekto arba nuovargio plyšio dydis neviršija leistinojo. Leistinajam plyšio dydžiui nustatyti tikslinga nagrinèti itempimu deformaciju būvị ir taikyti irimo mechanikos metodus.

Nagrinejjant plyšio susidaryma, plitimą ir atlikus išbandytụ smeigių lūžių analizę pastebèta, kad plyšio atsiradimo vieta kinta tarp gan plačiu ribų [6-12]. Lyginami smeigiu, pagamintu iš tos pačios medžiagos (plieno 25XIMФ), lūžiai. Todèl plyšio užuomazgy susidarymo mechanizmas turètų būti toks pat. Autorių nuomone, toks rezultatas gaunamas dèl sistemos veržlès poveikio varžtui, didelę itaka turi ir gamybos tikslumas (sriegio kampo ir žingsnio paklaida). Gali būti atskiras arba bendras šių paklaidu poveikis, keixiantis labiausiai apkrautos vietos padèti.

Atsižvelgiant i varžto ir veržlès sistemos gamybos paklaidas, irą̌̌u pasiskirstyma, plyšio atsiradimo ir plitimo dèsningumus, baigtiniu elementú metodu atlikta jungties M20 itempimų būvio analizè. Kadangi dèl gamybos netikslumu vijos apkraunamos netolygiai, apkrovos padétis vijos paviršiuje keičiama. 
Itempimų būvis ivertintas pagal Mizeso sąlygą. Itempimas

$$
\sigma_{i}=\frac{1}{\sqrt{2}} \sqrt{\left(\sigma_{1}-\sigma_{2}\right)^{2}+\left(\sigma_{1}-\sigma_{3}\right)^{2}+\left(\sigma_{2}-\sigma_{3}\right)^{2}}
$$

(čia $\sigma_{1}, \sigma_{2}, \sigma_{3}$ - svarbiausieji ịtempimai) imamas ịtempimy pokyčiui $\bar{\sigma}=\sigma_{i} /\left(F / A_{\text {min }}\right)$ nustatyti (čia $F$ visų apkrovų suma, $A_{\min }$ - varžto mažiausio skerspjūvio ties sriegio įduba plotas).

Pagal gautus skaičiavimo rezultatus galima išskirti tam tikrą sriti ịduboje, kurioje priklausomai nuo veržlès-varžto sriegio sąlyčio susidaro beveik vienodas itempimu būvis (parodytas 3 paveiksle): $1-2$ vijoje nuo $20^{\circ}$ iki $60^{\circ}$ (maksimalus itempimų pokytis 4,09); 0-1 vijoje nuo 5 iki $45^{\circ}$ (maksimalus itempimy pokytis 5,48 ) ir $1 '-0$ vijoje nuo $-15 \mathrm{iki} 20^{\circ}$ (maksimalus itempimu pokytis 2,75 ).
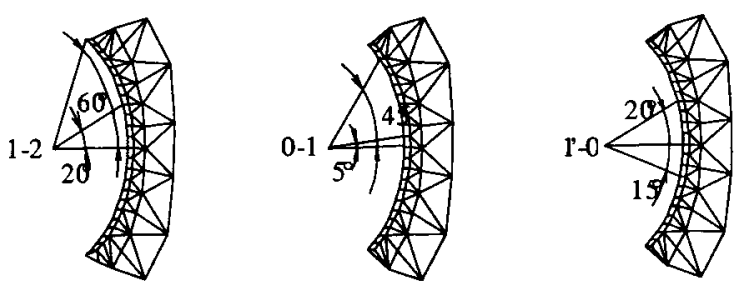

3 pav. Sriegio vijų idubos plyšio atsiradimo plokštumoje

Fig 3. Cavities of the turns of a thread in the threshold plane

Pirmosios vijos (0-1) iduboje susidaro beveik vienodos sąlygos plyšiui atsirasti. Tokiu salygu pasekme vienas arba keli plyšio židiniai ir didelis ką tik atsiradusio makroplyšio didejjimo greitis ties vijos įduba.

Atlikta ịtempimų būvio analizè paaiškina pagrindines plyšio susidarymo salygas ir tam tikrus ypatumus, nustatomus eksperimentiniais tyrimais. Anksčiau buvo manoma, kad tik atsiradęs plyšys padidina ịtempimų koncentraciją ir būtinai plinta, jeigu jègos poveikis nesikeičia. Tolesni tyrimai parodè, kad nuovargio plyšiai atsiranda, kai įtempimai mažesni už patvarumo ribą. Buvo aptikta tokių plyšiu, kurie neplinta, nors ciklų skaixius didejja, o itempimy amplitudé pastovi. Didesnès koncentracijos srityse jau ankstyvoje ciklinio apkrovimo stadijoje surasta plyšių, kurie plinta tik iki tam tikro gylio, o po to sustoja. Panašūs reiškiniai pastebėti ir mūsu atliktuose tyrimuose.

Pasinaudojus ankstesnių eksperimentinių tyrimų [10] rezultatais ir atlikus papildomus srieginių jungčiı iš plieno 25XIM $\Phi$ (normalizacija) tyrimus sudaryta kinetinès nuovargio diagramos dalis apkrovimo ciklų skaičiui, di- desniam kaip $10^{7} .4$ pav. pateiktos diagramos dalyje, kuri yra kinetinès nuovargio diagramos (1 pav.) tęsinys, negalioja lygtis (1). Ši dalis apibūdina trumpu plyšių plitimą Itempimų intensyvumo ribiné verte $\Delta K_{t h}$ yra slenkstis, žemiau kurio plyšiai neplinta.

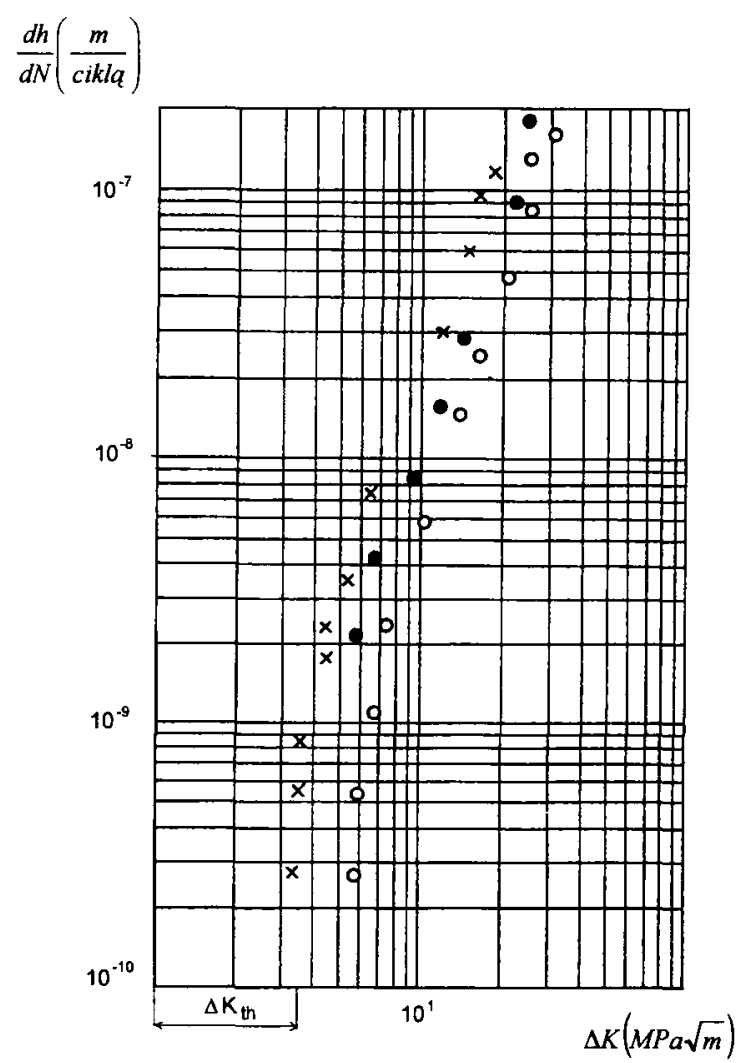

4 pav. Plyšio plitimo greičio priklausomybè srieginèse jungtyse M20 (plienas 25XIMF normalizacija): $0-I=0$; - $r=0,3 ; \quad x-r=0,6$

Fig 4. Dependence of the crack propagation rate in threaded joints $\mathrm{M} 20$ (steel 25XIMF normalising): $o-r=0$; - $\mathrm{r}=0,3 ; \mathrm{x}-\mathrm{r}=0,6$

Reikia pabrèžti dar vieną bandymo rezultatų ypatumą - mažiausiai du bandiniai (smeigè-veržlè) išbandyti vienodomis sąlygomis, tačiau plyšiai plito nevienodai. Ciklu skaičius iki plyšio atsiradimo abiejuose smeigès galuose nežymiai skyrèsi. Tuo tarpu ciklų skaičius iki visiško suirimo (kai kuriuose bandiniuose) žymiai skyrèsi. Taip pat plyšys viename iš smeigès galu gali sustoti. Autoriu nuomone, smeigeje plintantys plyšiai pakeičia ịrąžu srautus sistemoje smeigè-veržlè, dèl to sumažèja plyšio greitis arba plyšys sustoja.

Naudojantis eksperimentiniais duomenimis, taikant j̇tempimų būvio analizę, baigtinių elementų metodu buvo nagrinejama sritis, artima slenksčiui ( $\Delta K_{t h}$ pagal 4 pav.). 
5 pav. parodytas itempimų amplitudès pokytis sriegio vijos iduboje, atitinkantis tokius būvius: plyšys atsiranda ir plinta; plyšys atsiranda, tačiau sustoja ir plyšio neaptikta. Plyšio susidarymo ribiniu būviu imta lygaus bandinio patvarumo ribos amplitudè (punktyrinè linija 5 pav.), kuri nustatyta pagal priklausomybes [3, 7]. Pastebimas patenkinamas rezultatų sutapimas, kai ciklo asimetrijos koeficientas $r=0,3 ; 0,6$. Rezultaty skirtumas, kai ciklo asimetrijos koeficientas $r=0$, rodo nuovargio proceso sudetingumą ir veržlès poveikio varžtui ypatumus.

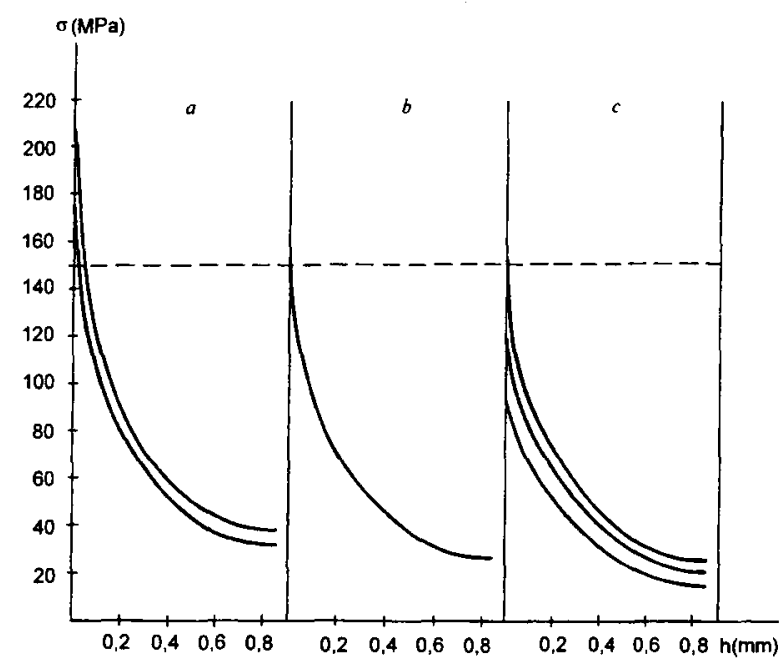

5 pav. Itempimu amplitudès pokytis sriegio vijos iduboje, kai ciklo asimetrijos koeficientas $r=0,6: a$-plyšys atsiranda ir plinta; $b$ - plyšys atsiranda ir sustoja; $c$ - plyšio neaptikta

Fig 5. The stress amplitude change in the cavity of the turn of the thread when the cycle ratio $\mathrm{r}=0.6 ; a-$ the crack forms and propagates; $b$ - the crack forms and stops; $c$ - no crack is revealed

Neplintančiu plyšių gylis gali būti apskaičiuotas pagal N. Frosto pasiūlytą priklausomybę:

$$
a=0,645\left(0,1 \sigma_{a}-1,6\right) \text {, }
$$

$\sigma_{a}$ - patvarumo ribos nominalinių itempimų amplitude. Nagrinèjamu atveju gauname, kad $a=0,16 \mathrm{~mm}$. Mūsų darbuose laikoma, kad minimalus stovinčio plyšio gylis nuo sriegio idubos $h=0,2 \mathrm{~mm}$. Manoma, kad tokiam gyliui galioja irimo mechanikos kriterijus $K_{1}$. Pagal eksperimentinius duomenis smeigèse M20 neplintančio plyšio ilgis yra apie $5 \mathrm{~mm}$, o gylis didesnis kaip $0,2 \mathrm{~mm}$. Atlikti smeigiu su tokiais plyšiais bandymai parodè, kad neplintantys plyšiai statiniam stiprumui itakos neturi ir suirimas ịvyksta lygioje dalyje. Nustatytas neplintančiu plyšiu dydis jau nesunkiai pamatuojamas neardančios kontrolès metodais tiek laboratorijos, tiek ir eksploatacijos sąlygomis.

6 pav. pagal duomenis $[6,7,8,9,10]$ pateiktos kinetinès nuovargio diagramos. Atskiros dalys 6 a pav. vaizduoja: I - mažu plyšių plitima; II - stabilų plyšio plitimą; III - staigu plyšio plitimą prieš visišką suirima. $6 \mathrm{~b}$ pav. parodyta srieginių jungčių M20 ir cilindrinių bandiniu su žiedine išpjova (imituojančia sriegio iduba) kinetinès nuovargio diagramos. Autoriu nuomone, atskiru diagramos ruožų skirtumai rodo veržlès poveikị varžtui ir kad irimo mechanikos pagrindinių dèsningumų (gautų reglamentuojamais bandymais) nepakanka aprašyti galimiems ribinių būvių susidarymo mechanizmams, plyšio atsiradimui ir plitimui, būdingam tik srieginèms jungtims.

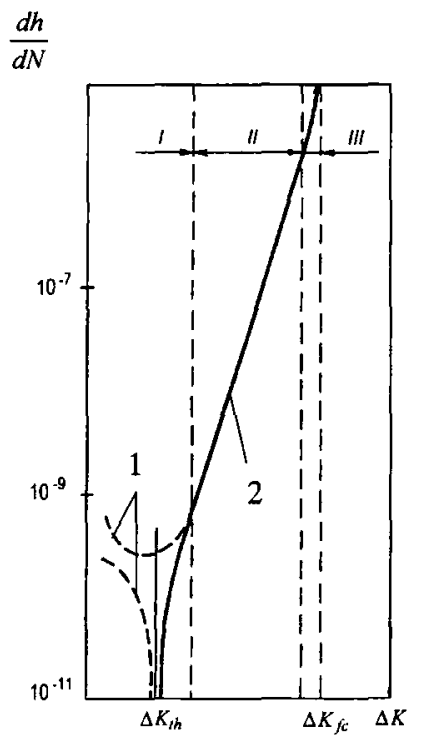

a)

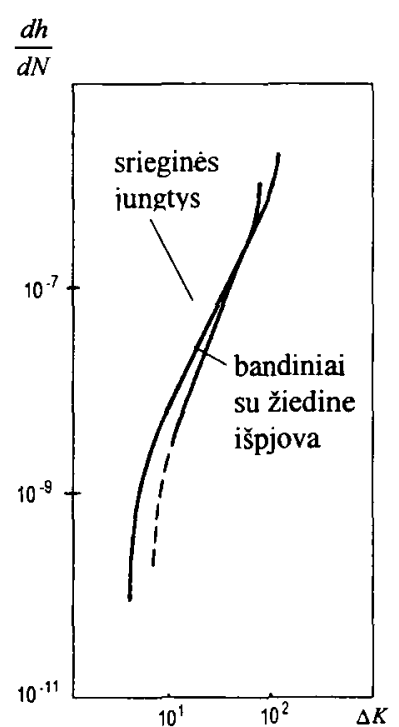

b)
6 pav. Kinetinès nuovargio diagramos: $a$ - bendrasis pobūdis; 1 - mikroplyšiai; 2 - makroplyšiai; $b$ - gautos darbe; - - skaičiuojamoji dalis

Fig 6. Diagram of kinetic fatigue: a - general character; 1 - microcrack; 2 - macrocrack; b - received at work, - - counting part

\section{Išvados}

1. Plyšio plitimo greiti, veikiant ciklinèms apkrovoms, patenkinamai aprašo irimo mechanikos kriterijus $\Delta K$ (itempimų intensyvumo koeficiento kitimo intervalas). Nepaisant plyšio plitimo ypatumų srieginese jungtyse, mažaciklio apkrovimo srityje, $\Delta K$ paprasčiausiai apskaičiuojamas ir gaunami pakankamo tikslumo rezultatai. Pagal nustatytas plyšio plitimo greičio priklausomybes 
galima apskaičiuoti srieginių jungčiu ilgaamžiškumą ir liekamaji resursa.

2. Srieginių lūžių analizè parodè, kad plyšio židinio vieta kinta tarp gana plačių ribų vijos įduboje. Nustatytas ryšys tarp srieginių paviršiu sukibimo pobūdžio ir ịtempimų būvio, kuris lemia plyšio susidarymo sąlygas ir židinio vietą. Taikant irimo mechanikos kriterijus (lygaus bandinio patvarumo riba $\sigma_{R}$ ir itempimy intensyvumo koeficiento slenksti $\Delta K_{t h}$ ), gautas patenkinamas eksperimentinių ir teorinių rezultatų (plyšio atsiradimas) atitikimas.

3. Skirtumas tarp kritiniu itempimu intensyvumo koeficientų: $K_{1 c}$-medžiagos (cilindriniai bandiniai su žiedine išpjova); $K_{t b}$-smeigès ir $K_{t c}$ - smeigès, sukibusios su veržle, - rodo skirtingą pasipriešinimą trapiajam suirimui. Tai priklauso nuo smeiges srieginio paviršiaus formos, plyšio fronto ir veržlès vijos palaikymo efekto, todèl trapuji irimą lydi ji stabdantys veiksniai.

4. Trumpi plyšiai (gylis iki $0,5 \mathrm{~mm}$, ilgis iki $5 \mathrm{~mm}$ ) nesumažina srieginių jungčių modelių M20 statinio stiprumo. Tai yra neardančios kontrolès metodais nesunkiai išmatuojamas plyšio dydis, kuri galima laikyti leistinuoju ribiniu būviu eksploatacijos sąlygomis.

\section{Literatura}

1. ASME Boiler and Pressure Vessel Code, Sec. III // Rules for Construction of Nuclear Power Plant Components, Div. I., Subsec. NB, 1995, p. 87-92.

2. ASME Boiler and Pressure Vessel Code, Sec. III // Rules for Construction of Nuclear Power Plant Components, Diw. I., Appendices, 1995, p. 6-12.

3. Нормы расчета на прочность оборудования и трубопроводов атомных энергетических установок. Москва: Энергоатомиздат, 1989. $525 \mathrm{c}$.

4. International standard. Threaded fasters. Axial load fatigue testing. Test methods and evaluation of results. ISO 3800 : 1993(E). Printed in Switzerland. 17 p.

5. И. А. Биргер, Г. Б. Иосилевич. Резьбовые соединения. Москва: Машиностроение, 1978. $256 \mathrm{c.}$

6. T. L. Anderson. Fracture mechanics. Fundamentals and Application. Boston: CRC Press., 1991. 794 p.

7. В. В. Панасюк, М. П. Саврук, С. Я.Ярема и др. Механика разрушения и прочность материалов. Киев: Наукова думка, 1988-1990, Т. 1. 488 с.; Т. 2. 620 с.; T. $3.436 \mathrm{c}$; T. $4.680 \mathrm{c}$.

8. В. А. Каган, А. И. Кренявичюс, М.- К. В. Ляонавичюс. Сопротивление разрушению образцов материала и элементов конструкций // Динамика и прочность конструкций. Вильнюс, 1980, с. 116-20 (Lietuvos aukštuju $\mathrm{m}$-lų $\mathrm{m}$. darbai. Lietuvos mechanikos rinkinys, Nr. 21).

9. В. А. Каган, М.-К. В. Ляонавичюс. Влияние механических свойств материала на развитие трешин малоцик- ловой усталости в резьбовых соединениях // Инженерные вопросы прикладной механики. Вильнюс, 1982, c. 93-101 (Lietuvos aukštujų m-lų m. darbai. Lietuvos mechanikos rinkinys, Nr. 23).

10. М.-К. В. Ляонавичюс, И. И. Жекявичюс, А. И. Кренявичюс. Сопротивление разрушению резьбовых соединений при циклическом асимметричном нагружении до $10^{6}$ циклов // Динамика и прочность машин и конструкций. Вильнюс, 1983, с. 146-154 (Lietuvos aukštujų m-lų m. darbai, Lietuvos mechanikos rinkinys, Nr. 25).

11. M. Leonavičius, S. Stupak. Itempimu būvio itaka plyšio susidarymui sriegio iduboje // Mechanika, Nr. 2. Kaunas: Technologija, 1998, p. 5-9.

12. M. Leonavičius and A. Krenevičius. Shakedown and Failure of the Threaded Joints under Low Cyclic Loading // Journal of Constructional Steel Research, Vol 46, 1998 / The Steel Construction Institute. Elsevier, p. 452-453. Special issue on CDROM.

Iteikta 20000204

\section{ANALYSIS OF CYCLIC FRACTURE OF THE THREA- DED JOINTS}

\section{Leonavičius, S. Stupak}

\section{Summary}

The initial production defects having been transferred into a structure and developed during its operation, it is crucial for labour safety to prevent such defects from reaching critical limits. First, the defects should be measured and then calculations of the parameters affecting the extent of their propagation are to be made. Provisions should be made to control damage during production and maintenance process. Evaluation of the structural element strength, once the defect or crack is detected, is rather a complicated procedure requiring sometimes additional theoretical solution or even an experimental research. The limit state conditions favouring stopping the crack find their way to practical application. If such conditions are maintained, it is estimated that the structural element containing a crack in a state of stoppage is able to perform fully its functions.

In the paper, the resistance of threaded joints to cyclic loading is defined and based on the criteria of fracture mechanics describing non-permissible operational limit states: formation of macrocrack; transition from stable crack propagation to a dynamic one, ie fracture of the structural element; stable crack propagation exceeding the permissible crack size; transition from the defect (stable crack) to steadily propagating crack, ie continuous accumulation of damage.

The regularities of the fracturing process, taking into account constructive peculiarities, production technology and loading conditions were studied in threaded joints within the range of M8 to M48. Threaded joints were tested according to the system 'nut-stud-nut' and 'nut-stud-body' made of steel 25XIM $\Phi$ and 20XIMIФITP which are widely used to manufacture elements for fixing power equipment. The indicators of mechanical properties are as follows: $\sigma_{0.2}=780 \div 1020 \mathrm{MPa}$; $\sigma_{u}=830 \div 1120 \mathrm{MPa} ; \psi=58 \div 62 \%$. Nuts were manufactured from the same kind of steel as studs, or from another kind of steel with different mechanical properties.

The characteristic stages of crack propagation and its rate along the cavity and deeper into the cross-section are presented 
in the works of the authors. In the experiments, the criterion of fracture mechanics $K_{1}$ was applied to describe the crack propagation rate and to investigate the conditions of brittle fracture. A special investigation was carried out to substantiate such a decision. On the basis of the refraction obtained, the S. Jarioma equation was applied to calculate the stress intensity ratio. The parameters of kinetic the fatigue diagrams (a threaded joint and cylindrical specimen 20 with a ring notch imitating the cavity of thread M20) described by means of the P. Paris equation are presented in the works of the authors.

The presented experimental data of the cyclic fracture strength of models M20 are characteristic of threaded joints of other size too, not only of those with the size ranging from M8 to M48. Similar regularities were observed in natural specimens of threaded joints M140x6. The low-cycle fatigue strength of threaded joints manufactured from steel with different mechanical properties (studs made of steel 25XIMФ, nuts of steel $20.40 \mathrm{X}$ and $\mathrm{TC}$ ) change insignificantly. A more uniform distribution of notches were observed, however, it has a minimal effect on threshold and crack propagation.

To determine specific peculiarities which are characteristic of threaded joints, additional experiments were carried out. It is known that a properly constructed threaded joint 'nut-studnut' undergoes fracture in the stud bar during the construction loading (as in case of tension). Provided there is a big crack in the stud, the fracture can occur on the plane of the cavity during the construction loading. Specimens of three types were studied as follows: cylindrical specimens with a crack; studs with a crack and threaded joints 'stud-nut' with a crack in their studs. The results of the experiment depending on the depth of the crack are presented. Different regularities of the threshold, crack propagation and its brittle fracture can be explained as follows:

- a different stressed state within the cavity of the stud thread (the total result of the stud tension and turn bending) and in the ring notch of the cylindrical specimen;

- a different front of crack propagation;

- a different angle of crack propagation (perpendicular to loading in the cylindrical specimen and along the angle of the rise of a turn in the stud);

- the effect of the first joint turns of the stud and the nut which limits crack opening and influences the processes taking place on the top of a crack.

All these factors determine a certain difference between the intensity ratios of critical stresses: materials $K_{c}$; studs $K_{c b}$ and studs joint to the nut $K_{c t}$.
Making use of earlier and additional experimental investigation of threaded joints made of steel 25XIM $\Phi$ (normalising), the part of the diagram of kinetic fatigue was drawn in which the number of loading cycles exceeds $10^{7}$. This part characterises the propagation of short cracks. The marginal value $\Delta K_{t h}$ of the intensity of stresses is a threshold below which cracks do not propagate.

One more peculiarity of the experiment results should be indicated - at least two specimens (stud-nut) were tested under equal conditions, but the cracks propagated differently. In the opinion of the authors, cracks propagating in the stud change the flows of the internal resultant in the system 'stud-nut' as a consequence of which the crack propagation rate either decreases or terminates.

Making use of the experimental data and analysis of the stressed state, the study of the region close to the threshold ( $\Delta K_{t h}$ ) was conducted by means of finite element method. The amplitude of the endurance limit of an even specimen is regarded as the limit state of the threshold. A satisfactory correlation of the results was observed with the stress ratio $r=0 ; 0.3 ; 0.6$. The difference in the results with the stress ratio $r=0$ shows the complexity of the fatigue process as well as the peculiarities of the effect of the nut upon the bolt.

According to the experimental data, the length of a nonpropagating crack $\approx 5 \mathrm{~mm}$, and the depth exceeds $0.2 \mathrm{~mm}$. Experiments carried out on studs with such cracks showed that non-propagating cracks have no effect on the static strength and fracture takes place in an even part. The determined size of nonpropagating cracks is easily measured by means of nondistrusting control methods both under laboratory and operational conditions.

Mindaugas LEONAVIČIUS. Doctor, Associate Professor Dept of Strength of Materials. Vilnius Gediminas Technical University, Sauletekio al. 11, LT-2040 Vilnius, Lithuania, e-mail ma@fm.vtu.lt

Doctor (structural mechanics, 1977). Research interests: fracture mechanics and shakedown.

Stanislav STUPAK. Doctor, Associate Professor. Dept of Strength of Materials. Vilnius Gediminas Technical University, Sauletekio al. 11, LT-2040 Vilnius, Lithuania,

e-mail stupakas@adm.vtu.It

Doctor (structural mechanics, 1978). Research interests: analysis of elastic-plastic strain hardening structures and shakedown; fracture mechanics. 